\title{
E-Participation of Selected Professional Students in the Governance of Cabanatuan City in the Philippines
}

\author{
Ofelia M. Bawan', Maria Isidra P. Marcos², Arneil G. Gabriel ${ }^{1}$ \\ ${ }^{1}$ Department of Public Administration, Nueva Ecija University of Science and Technology, Cabanatuan City, Philippines \\ ${ }^{2}$ College of Information and Communications Technology, Nueva Ecija University of Science and Technology, Cabanatuan City, \\ Philippines \\ Email: opats14@yahoo.com
}

How to cite this paper: Bawan, O.M., Marcos, M.I.P. and Gabriel, A.G. (2017) E-Participation of Selected Professional Students in the Governance of Cabanatuan City in the Philippines. Open Journal of Social Sciences, 5, 126-139. https://doi.org/10.4236/jss.2017.512010

Received: November 16, 2017 Accepted: December 16, 2017 Published: December 19, 2017

Copyright (๑) 2017 by authors and Scientific Research Publishing Inc. This work is licensed under the Creative Commons Attribution International License (CC BY 4.0).

http://creativecommons.org/licenses/by/4.0/ (c) (i) Open Access

\begin{abstract}
The strength of democracy is measured through citizens' participation in governance. To check the applicability of this theory in local context, the study determined the actual observance of a purposively selected group of professionals pursuing post graduate degree in Public Administration in the Philippines. Using Arnstein Measure of Community Participation, the paper found that there is low level of e-participation among participants as shown by their frequency of access and level of awareness on the city website. Strict adherence to the principle of e-democracy in actual practice is necessary. The paper concluded that electronic participation in governance is both a responsibility and a privilege. There is a need to improve citizens' willingness to participate in local governance via electronic means. E democracy cannot stand in isolation from citizens' participation. The study recommended that the Local Government Unit (LGU) should look for ways to bolster citizens' use of the city website as a vehicle for democratic reforms and participation.
\end{abstract}

\section{Keywords}

Information and Communications Technologies, E-Democracy, E-Participation, Graduate Students, Local Governance

\section{Introduction}

The 1987 Philippine Constitution provides that, "Philippines is a republican and democratic state, sovereignty resides in the people and all government authority emanates from them" [1]. As a democratic state, the Philippines observes direct 
and indirect democracy. Direct democracy is present when the citizens themselves participate in decision making and indirect democracy when participation is through chosen political leaders who speak for the interests of a well defined group [2]. E-democracy can be understood as civic participation through the use of digital means to enable the powerless citizens to influence and take part in crucial political decision making in the government. Thereby effectively diffuses to a certain extent the over concentration of political power to government officials and elected political leaders.

Sherry Arnstein in 1969 argued that citizen participation is "synonymous to the present concept of inclusive governance where marginalized and powerless citizens could take part in governmental decision making and induces social reform which could make them share in the benefits of the affluent society" [3]. In the realm of decision making, governmental planning and local legislation, participatory governance is a sine qua non for successful policy implementation. Participatory governance aims to enhance the power and influence of powerless citizens in the process of governance [4]. Through participatory governance, ordinary citizens find ownership of governmental decisions and increased motivation for their observance [5]. It is a governance strategy that requires promotion and analysis of active "vertical" and "horizontal" relationship and interaction existing between citizens and government to strengthen the relationship between state and its people [6]. Citizens' participation in governance creates greater transparency and accountability. It is an important component of democratic government [7]. It creates wider latitude for citizens' participation that promotes transparency and accountability in government transactions [8]. Participatory governance in local legislation has a strong positive correlation to legislative performance [9].

The advent of information technology intensifies opportunities available to the people to participate in governance by electronic means also known as E-participation. The proliferation of computer and development of digital technology, changes the way people participate in governance [10]. The social media and web based platform of information exchanges dominates the day to day political participation and discussion [11]. The emergence of new and novel ideas of mechanism for expression such as e-democracy, e-bureaucracy and e-services are now becoming popular [12]. The use of information technology dramatically improves service delivery and increase efficiency and public accountability arising out of wider window for public scrutiny of government transactions [13]. The United Nations for instance, came out with a study on the importance of active citizens participation on line, termed as e-participation and came out with the stern warning that if the government wants to maintain its complete control, the government must face the challenge to develop technological mechanisms designed to facilitate citizens' participation [14]. The internet and computer as tools of Modern Public Administration make government documents more accessible, faster and reliable [15]. 
E-democracy in this study is conceived as dispersion of governmental power by providing wider space for civic participation and civic engagement to influence political decision making in the local government context via digital technology. E-democracy is closely interlinked with e-participation. Electronic participation is civic engagement through web based channel of communications intended to influence decision making in all areas of local government operation. It is more on the measurement of the selected professionals' initiative to take part in governance by means of information sharing, exchanges and dissemination using electronic means [16].

\section{Research Problem}

The study tried to measure the level of selected professional students local governance engagement using web based platform and channel of communication using Arnstein's ladder of community participation. Specifically, the study sought answer to the following questions:

1) How may the selected professional students' awareness on the existence of LGU website be described?

2) How often do selected professional students visit the LGU website?

3) Why do selected professional students access the local government website?

4) How may the exact level of online civic engagement of selected professional students be described using Arnstein's ladder of participatory governance?

\subsection{Methodology}

The study described the manner selected professional students participated in the administration of their local government unit by using website and the internet. It is a descriptive research used to check actual practice against the theoretical foundation of electronic democracy. The Cabanatuan City government official website was used as a tool to gather data on the manner selected professional students participated in local affairs using web based channels of communication. Through questionnaires, interviews and observations, the study determined the level of selected professional students' participation in local governance using electronic means. Analysis of graduate students' exact degree of participation was measured using the eight tiers model for participatory governance developed by Sherry Arnstein in 1969. Questionnaires were developed and purposive sampling method was observed. The criteria for the determination of sample are as follows:

a) Residents of Cabanatuan City; b) currently enrolled in the graduate program, major in Public Administration; c) not employees of the local government unit under consideration; and d) a registered voter of the City. Through the application of the criteria a total of 52 participants were selected.

\subsection{Theoretical Framework}

The strength of democracy is measured through citizens' participation in local 
governance. The study is guided by the principle that citizen participation is citizens' power [17]. A true democratic system rests on the will of the people expressed in terms of dialogue and citizens participation in decision making through popular election and deliberative processes [18]. The strength of democracy is measured on how citizens take part in governance because greater participation contributes to better governance [19] According to Arntein (1969), there are three general types of community participation. Depending on the type of participation, the exercise of power of citizens is measured. The three types of participation are: a) non participation, b) tokenism and, c) citizen power [3]. Each of the major type is consisting of subcategories of participation. The non participation for instance, is composed of manipulation and therapy. Tokenism as a measure of participation is composed of informing, consultation and placation. The highest level of participation is made up of partnership, delegated power and citizens' control. Each of this type and categories qualitatively measures citizen's participation in governance. E- participation and E-democracy: Level of Participation of Selected Professional Students in the Governance of Cabanatuan City in the Philippines is made to measure the exact citizen's participation in local governance of the Cabanatuan City government via the web based tools. Such degree of participation shows to a great extent the local government's adherence to the democratic precept of government by the people and governance principle of community participation in local affairs management. These are the two precepts serving as the foundation of a strong democratic local government [20]. Through the study, the respondents manner of political and civic engagements, may unravel the "myths" of e-government.

The theory of Arnstein is applied by looking into the two sides of local governance. The demand side (people) and the supply side (local government unit [21], the former emanated from ordinary citizens, the latter from the government instrumentality. Ideally, the two must complement to each other to form a political consensus of democracy in local governance. The peoples' demand as expressed through web based civic engagement and the supply side expressed in terms of responsiveness to demands. The study adheres to the principle that democracy is measured through citizen's engagement with the government itself [22]. Without citizens' participation democracy has no feet to stand on. Therefore, the paper argued that citizen engagement reflects the willingness of the power holders to share governance with the constituents. But sharing of power is a process which involves development of habit and processes attuned to democratic participation on the part of the citizens themselves. The participation is considered in whatever medium. In the case of the study area, it is through the Information Technology (IT) platform.

\section{Conceptual Framework}

The study is premised on the conceptual framework of E commerce Act of 2000 and based on the goal that by 2010 all public institutions must serve as role 
model to private corporations in terms of investment and use of website and the internet. The private corporation shall cooperate and coordinate as well as emulate government agencies in their thrush of providing governance services and information via website. It has also the mandate to engage in partnership agreement and investment with the government in the area of information technology infrastructure and building information platform. In the use of information technology, communication between citizens and government increases resulting in civic engagement and greater degree of democratic participation [23]. The following diagrammatic presentation of conceptual analysis of the study shows how the process of democracy is strengthened by electronic participation. As shown in Figure 1, the box on left side represents the duty of Local Government Unit to establish IT platform as a means to provide transparency in governance and in compliance to the mandate of the law. Such IT platform is availed of by citizens in numerous ways. The lowest form of IT engagement is to access information of the local government unit. Citizens are researching on the services and departments of the LGU. There is no interaction between the local government side on the one hand and citizens on the other hand. This phase exemplifies the right of citizen's to have access to information of public interests. The stage is guided by full public disclosure of information.

The second phase of development in using IT platform in governance is the interaction phase. The Citizens on the one hand, interact with government officials via e-mail, facebook, twitter or other mass and social media format and the delivery of services thru electronic means when applicable. The E-Commerce Act of 2000 mandates the government to provide platform for electronic engagement with citizens. Accordingly,

"Within two (2) years from the effectively of this Act, there shall be installed an electronic online network in accordance with Administrative Order 332 and House of Representatives Resolution 890, otherwise known as RPWEB, to

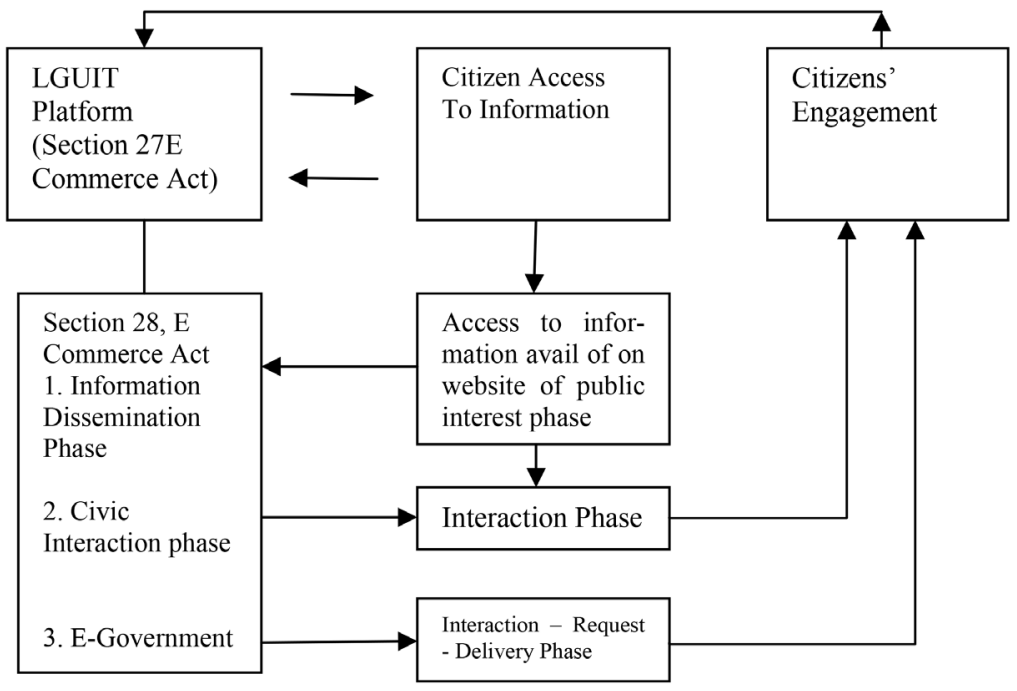

Figure 1. Conceptual framework for e-Democracy in local governance. 
implement Part IV of this Act to facilitate the open, speedy and efficient electronic online transmission, conveyance and use of electronic data messages or electronic documents amongst all government departments, agencies, bureaus, offices down to the division level The RP WEB is the means to deliver services by all government agencies".

In fact it requires that:

The RPWEB network shall serve as initial platform of the government information infrastructure (GII) to facilitate the electronic online transmission and conveyance of government services to evolve and improve by better technologies or kinds and electronic online wide area networks utilizing, but not limited to, fiber optic, satellite, wireless and other broadband telecommunication mediums or modes" (Section 28, E Commerce Act).

In this particular phase of public governance thru information technology development, the interaction between citizens and government is not just to get information but to react on request for information available through the website. In this phase, decision making and consultation activities are part of routine execution of duties of the local government. This phase is marked with civic engagement phase. As depicted in Figure 1, local officials and electorates shared in the crucial information sharing pertaining to governance and requiring popular support or administrative-politico decision making.

The last and final phase of public governance through information technology is the interaction-request-and delivery phase where services needed are done via the internet and web facilitation e.g. permits, licenses, authenticated certificates and the like. This phase is the highest Information Technology development phase where citizens' participation is at its maximum. Therefore, the study posits that there are two crucial phases in the development of information technology in governance: the interaction phase and the interaction-request-delivery-phase. They are both treated by the study as acts of civic engagement. The conceptual framework when coupled with the theoretical framework of Arnstein measure of community participation can effectively assess the degree of civic engagement and participation that graduate students' availed of in the governance of the locality. The study was done during the Academic Year 2012-2013.

\section{Results and Discussion}

The professional students' knowledge on the existence of Cabanatuan City website is shown on Table 1. Based on data presented, 27 of the respondents are fully aware of the existence of City government website. A total of 46 respondents knew that they could access the city government through the internet. Interviews showed that professional students primary source of governance information is through television channel 11 and radio station DWJJ, a radio station owned by the City. Still, some said that knowledge on the web site is through the employees of the City.

The table also indicates respondents' knowledge on the city government website (Item 15) which shows that 48 or 92 percent of professional students have 
Table 1. Selected professional students' knowledge on the existence of the city website.

\begin{tabular}{lcc}
\hline \multicolumn{1}{c}{ Item Number } & Frequency & No \\
\cline { 2 - 3 } & Yes & 4 \\
\hline 1) I have a set of personal computer unit & 48 & 6 \\
2) I access the internet & 46 & 19 \\
3) I connect the internet using public service & 33 & 9 \\
4) I connect the internet using private settings & 43 & 41 \\
5) I enter in the chat room & 11 & 45 \\
6) I have personal webpage & 7 & 34 \\
7) I have my own web account & 18 & 41 \\
8) I have a twitter account & 11 & 0 \\
9) I have e-mail address & 52 & 0 \\
10) I have face book account & 52 & 0 \\
11) I send or receive e-mail via the internet & 52 & 7 \\
12) I have a website regularly visited & 52 & 25 \\
13) I am aware of the Cabanatuan City webpage & 27 & 31 \\
14) I have accessed the Cabanatuan City webpage & 21 & 47 \\
15) I accessed the page for civic engagement & 5 & \\
\hline
\end{tabular}

personal computers while 46 or 88 percent of the respondents have internet connections. A large number of respondents' have the potential to connect and access government website. This explains why a total of forty three 43 or 90 percent of 48 participants with personal computers accessed the internet using private settings.

The data also show that 49 of the 52 participants equivalent to 94 percent of the total respondents claimed that they accessed the internet for research purpose. The responses also show that 52 or 100 percent of the selected professional students had e-mail address and experienced sending or receiving mail or information using their e-mail address. This is a positive sign that the respondents can avail of the technological advancement which can be used to process reliable and accurate information when and where they are needed. Among the respondents, 45 or 87 percent of the respondents revealed that they regularly visited some websites. According to interviews, those websites have something to do with research and educational information necessary to aid them finish their report, assignment or term paper in the graduate program. Out of 52 participants or 87 percent of the total respondents, only 21 or 45 percent have accessed the Cabanatuan City web site. This finding is supported by the fact that only 27 or 52 percent of selected professional students are aware that the City government maintains website where electorate could access and take advantage of, to share views, participate in decision making and discuss pressing issues confronting them. 
On the other hand, 25 or 48 percent of the respondents are not aware that the City government has a website. While only 27 respondents or 52 percent claimed that they knew the existence of websites. Meanwhile, 36 respondents of the 48 who have personal computers, or 69 percent consider lack of time and being preoccupied with other concerns as the factors preventing them from participating in public governmental decision on line. This goes to show that aside from being unaware, those who are aware constitute only a small portion of the total number of respondents and they needed time to access and undertake civic engagement.

Table 2 shows that only 21 of the graduate student respondents have accessed the Cabanatuan City website. Such number of students consists of 40 percent of the total number of respondents. Many accessed the website for curiosity purpose. Many of them narrated that they seldom access the City website. Access is done occasionally and not a matter of personal obligation to be informed of what is going on in the city.

Table 2 also presents the responses of graduate students in so far as frequency of and the category of website services visited. The graduate students visit three websites most often: the social networking site (facebook, twitter), messaging website, and research website. They are chosen by 100 percent of the respondents and the frequency of visit ranging from once every six months to everyday.

The finding reveals that the mentioned websites are indeed potential tools for advancing political interest. They have also the potential to promote and widen democratic participation in local governance as found in most articles written by political social scientist. Social networking and messaging websites got the two

Table 2. Selected professional students' frequency of visit to website.

\begin{tabular}{|c|c|c|c|c|c|c|c|}
\hline \multirow[b]{2}{*}{ Item Number } & \multicolumn{3}{|c|}{ Frequency } & \multirow[b]{2}{*}{$\begin{array}{c}\text { Once a } \\
\text { week }\end{array}$} & \multirow[b]{2}{*}{ Everyday } & \multirow[b]{2}{*}{ Total } & \multirow[b]{2}{*}{$\%$} \\
\hline & $\begin{array}{l}\text { Once } \\
\text { a year }\end{array}$ & $\begin{array}{c}\text { Once } \\
\text { every six } \\
\text { months }\end{array}$ & $\begin{array}{l}\text { Once a } \\
\text { month }\end{array}$ & & & & \\
\hline 1) Banking website & 0 & 0 & 9 & 2 & 0 & 11 & $21 \%$ \\
\hline 2) Commerce and trade website & 0 & 0 & 15 & 0 & 0 & 15 & $40 \%$ \\
\hline 3) Entertainment website & 0 & 0 & 10 & 4 & 0 & 14 & $26 \%$ \\
\hline 4) Local government website & 0 & 10 & 11 & 0 & 0 & 21 & $40 \%$ \\
\hline 5) Messaging website & 0 & 0 & 21 & 6 & 25 & 52 & $100 \%$ \\
\hline 6) Nationa government website & 0 & 5 & 10 & 0 & 0 & 15 & $29 \%$ \\
\hline 7) Research website & 0 & 5 & 16 & 31 & 0 & 52 & $100 \%$ \\
\hline 8) Social networking website & 0 & 0 & 6 & 10 & 36 & 52 & $100 \%$ \\
\hline 9) Sports website & 0 & 0 & 9 & 11 & 0 & 20 & $38 \%$ \\
\hline 10) Travels and tours website & 6 & 14 & 0 & 0 & 0 & 20 & $38 \%$ \\
\hline Total Frequency & 6 & 10 & 10 & 33 & 61 & 272 & $72 \%$ \\
\hline
\end{tabular}


highly visited websites having 61 and 33 respondents saying that they visited the website everyday and every month respectively. Banking and national government websites are the least visited websites. The local government website is visited by 40 percent of the respondents. The table indicates enough opportunities to access the government website. However, most often than not, it is the social networking site that is visited by the graduate students. Although looking into the various discussions in the social networking website visited, some of the subject of conversations are political in complexion and has something to do with local and national governance. It is noteworthy to mention here that political culture in the Philippines is pervaded by personalism. This could be the reason why graduate students talked about politics in social networking site and among themselves instead of directly communicating their opinions through ICT with the people in power. That the Philippine political culture is so personal that objective interpretation of things political must always consider the openness of the political leader to listen or otherwise be offended personality by the objective political position of the electorate on a certain issue. This requires the government to take the lead to encourage citizens' participation towards democratic reforms if it wants electronic democracy to thrive and realize. Electronic participation should not be treated by the government and political leaders as a discreet activity among and between citizens and the government but instead a day to day activity sine qua non and a prerequisite in the management of democratic institution.

Table 3 shows that only five out of the 21 respondents or barely 21 percent of the respondents who accessed the website claimed that they accessed the site for civic engagement purposes. Some would send e- mail containing position on certain issue or to send feedback on the services provided. A greater majority opined that such accessed was intentionally made to solicit latest information concerning the Cabanatuan City Government and not for interaction purpose.

Table 3. Selected professional students' reasons for accessing the local government website.

\begin{tabular}{|c|c|c|c|}
\hline Item Number & YES & NO & TOTAL \\
\hline 1) To inquire into the government services on the City webpage & 21 & 31 & 52 \\
\hline 2) To access public records & 21 & 31 & 52 \\
\hline 3) To inquire into the City budget & 21 & 31 & 52 \\
\hline 4) To look into approved city ordinances or resolution & 21 & 21 & 52 \\
\hline 5) To influence policymaking & 5 & 47 & 52 \\
\hline 6) To cast votes on a local issue & 0 & 52 & 52 \\
\hline 7) To attend public hearing through the internet & 0 & 52 & 52 \\
\hline 8) To oppose government decision on a certain issue & 0 & 52 & 52 \\
\hline 9) To complaint city government personnel service & 5 & 47 & 52 \\
\hline 10) To provide feedback to the city government & 5 & 47 & 52 \\
\hline
\end{tabular}


Majority or 49 out of 52 students accessed the websites not the Cabanatuan City website to do their research requirements in the graduate program. Indeed, the internet is a rich source of data necessary to do research. The website maintained more than 5 billion stored information, from which relevant information and reading materials may be selected to bolster research output [24]. The varied reasons for accessing the City website through a multiple response survey questionnaires are shown on Table 3; 21 of the respondents who accessed the Cabanatuan City website did so to inquire into the basic information pertinent to the LGU operation as solicited by items $1,2,3,4$. Implicitly, the table reveals that 100 percent of those who accessed the LGU website would like to have the basic information and not for the purpose of civic engagement. The first phase in the development of electronic democracy and participation is access to information. However, such gesture is only at the lowest rung of Arnstein participatory governance theory. It is a one side interaction where the government provides information to comply with the mandate of Freedom of Information Executive Order No.2 and the E-Commerce Act of 2000. It is barest of all the LGU responsibilities in respect to openness in operation and transaction. In addition, Table 3 reveals that 5 of 21 respondents who were able to accessed the LGU website did the same to provide feedback and to complaint government personnel in regard to his or her delivery of service to the respondents. The Philippine bureaucracy is known for inept, slow and unsatisfactory rendition of services to the public. This image of the bureaucracy considerably causes a decline in the trust of the citizens to public institutions [25] Thus, it is normal in the LGU that a private citizen complains of a personnel for a lousy services rendered. It shows that 5 out of 21 respondents claimed that they availed of the internet to correct the bad habit of government personnel. Also, 5 of the 21 respondents who had access the website of the City did it to influence policy making. And some did the same to oppose the action of the City on a certain issue. All the 5 respondents revealed the fact that they are somehow near to actual civic engagement.

E-democracy is not favored by most politicians due to its threat to their political positions. E-democracy is of the nature of power sharing whereby ordinary citizens may have the chance to question the acts and decisions of people in power. E-democracy is also a means available to political opponents to reveal the shortcomings of the incumbent. E-democracy uses Information Technology to make elected officials more accountable to the voting public. The responses reveal that graduate students seldom use the internet for democratic practice. The internet is used for e-government more than for e-democracy. The reasons presented above having higher degree of responses are items pertaining to e -operation rather than e-democracy. All in all there are only 21 respondents or 40 percent out of 52 respondents who claimed that they have accessed the Cabanatuan City website to participate in local government operation.

In the light of what has been narrated by the respondents, it is clearly shown that e-democracy is far from its realization in the local context. The concept of e democracy is for the citizens to partake of governance responsibility. It is a 
means that appeals to the motivation of the people who would avail of the means. And most likely, and in the absence of ordinary citizens partaking of local governance via the internet, the political opponents of the incumbent politician who would avail of the means to decrease the chances of re -election of the incumbent. It is also the reason cited that some of the crucial records and decisions made by the incumbent are not posted on the webpage.

E-democracy is building a consensus out of political agreement and disagreement among political actors. But when the most important element of e-democracy, that is citizens participation, is lacking, information technology can only be used by politicians to control the release of information to the detriment of democratic institution and in some parts of the globe, even put up a totalitarian regime. Therefore, reshaping the democratic space through e-participation is more of a duty of every citizen. Strengthening democratic space relies greatly on the exercise of the privilege vested in every electorate. As all democratic systems in world would guarantee, the Philippines is a democratic system where sovereign power resides in the people and all government authority emanates from them. E-democracy is not democracy without adequate citizens' participation. United they stand, divided they fall.

\section{Conclusions}

Development in digital technology provides impetus for the changing political landscape. The advent of computer undeniably made the life of citizens more convenient but also contributed to efficient and effective management of public and private organizations. The local government unit being in the forefront of countryside development takes advantage of this technology. As the study showed, the knowledge of graduate school students on the existence of local government website is considerably high. But the frequency of access (participation) to the Cabanatuan City website is extremely low. Many did not even access the website to get information pertaining to local governance posted on the webpage. Many are having the potentials to access the website and influenced local governance but only a few did. Majority are preoccupied with other concerns (academic requirements) that they did not avail of the opportunity to influence local governance via the internet. The level of participation if there is, can be considered as non participation. This is the level that Arnstein level of community engagement refers to as either manipulation or placation.

Electronic participation in local governance is both a responsibility and a privilege. The data showed that only five (5) of the graduate students who are residents of Cabanatuan accessed the web for information purpose. None of them did so for civic interaction or participation. Thus, the importance of information technology to local governance is negated by their complacent attitude towards the use of computer to contribute to local development and governance. Particularly in the areas of: 1) planning, 2) decision making and 3) political mobilization. The graduate school students are professionals and a reservoir of potential technocrats, bureaucrats and think tanks useful for local government adminis- 
tration and development. By the nature of their courses enrolled and their academic training and preparation, it is surprising to note that majority have not taken advantage of government websites to influence decision making in local setting.

The effort of the local government units to put up Information Technology infrastructure cannot bear sufficient fruits if the manner and mechanism for the use of modern technology for political participation is not known and availed of by its constituents. As the E-Commerce Act provides, it is mandatory for LGU to allot funds and personnel to build IT infrastructure and platform for citizen's participation. Therefore, not much is gained when citizens themselves are not availing of the medium for local governance participation. The development and applicability of modern technology to governance depends to a great extent on the willingness of citizens to take part in a democratic governance.

In view of this observation, it is recommended that:

The Local Government Unit of Cabanatuan to undertake government led initiative to increase the level of awareness of its constituents on the potential of web and internet for citizens' active participation. And for the concerned citizens, including the graduate students to spearhead the task of participatory governance by taking advantage of the availability of internet and government websites to take part in crucial public decision making process. Meanwhile, the institution of higher learning may strengthen linkages to local government by requiring students to do research on local government administration. The future researchers may come up with studies measuring the degree of participation of citizens in governance. These would provide an accurate evaluation of the local government unit's observance of democratic precepts and participatory governance independent and separate from the claim and pronouncement of the local government unit involved. After all, participatory democracy and governance are the business of citizens and government. Participatory democracy is a government of consensus where decision is a product of political agreements or disagreements. It is a responsibility of the parties in a social contract. It is neither imposed nor presumed by one of the contracting parties.

\section{Acknowledgements}

My gratitude to my students in the NEUST Graduate School who participated in the study as respondents and to Mr. Anthony San Pedro for manuscript encoding.

\section{References}

[1] De Leon and Lugue (1982) Textbook on the Philippine Constitution. Manila Philippines. Rex Bookstore, Nicanor Reyes St. Morayta.

[2] Svensson, P. (2007) Direct and Representative Democracy- Supplementing, Not Excluding Each Other. Ikke Angivet.

[3] Arnstein, S.R. (1969) A Ladder of Citizen Participation. Journal of the American Institute of Planners, 35, 216-224. https://doi.org/10.1080/01944366908977225 
[4] Reddel, T. and Woolcock, G. (2004) From Consultation to Participatory Governance? A Critical Review of Citizen Engagement Strategies in Queensland. Australian Journal of Public Administration, 63, 75-87.

https://doi.org/10.1111/j.1467-8500.2004.00392.x

[5] Fung, A. and Wright, E.O. (2001) Deepening Democracy: Innovations in Empowered Participatory Governance. Politics \& Society, 29, 5. https://doi.org/10.1177/0032329201029001002

[6] Amoretti, F. (2007) International Organizations ICTs Policies: E-Democracy and E-Government for Political Development. Review of Policy Research, 24, 331-344. https://doi.org/10.1111/j.1541-1338.2007.00286.x

[7] Gabriel, A.G. (2017) Transparency and Accountability: Levels of Commitment of Municipal Councilors in Bongabon in the Philippines. Asia Pacific journal of Public Administration, 39, 217-223. https://doi.org/10.1080/23276665.2017.1368902

[8] Holzer, M. and Hu, L.-T. (2004) Digital Government and Citizen Participation in the. Digital Government: Principles and Best Practices, 306.

[9] Gabriel, A.G. and Gutierrez, M.P. (2017) Praxis in Local Legislative Governance: Measure of Organizational Effectiveness of the Component Cities in Nueva Ecija Philippines. Asia Pacific Journal of Multi Disciplinary Research, 12-20. http://www.apjmr.com/wp-content/uploads/2017/04/APJMR-2017.5.2.02.pdf

[10] Dannug, R.R. and Campanilla, M.B. (2003) Politics, Governance and Government with Philippine Constitution. Publisher not identified.

[11] Gil de Zúñiga, H., Jung, N. and Valenzuela, S. (2012) Social Media Use for News and Individuals' Social Capital, Civic Engagement and Political Participation. Journal of Computer-Mediated Communication, 17, 319-336. https://doi.org/10.1111/j.1083-6101.2012.01574.x

[12] Bovaird, T. and Löffler, E. (2002) Moving from Excellence Models of Local Service Delivery to Benchmarking "Good Local Governance". International Review of Administrative Sciences, 68, 9-24. https://doi.org/10.1177/0020852302681001

[13] Welch, E.W. and Wong, W. (2001) Global Information Technology Pressure and Government Accountability: The Mediating Effect of Domestic Context on Website Openness. Journal of Public Administration Research and Theory, 11, 509-538. https://doi.org/10.1093/oxfordjournals.jpart.a003513

[14] Moon, M.J. (2002) The Evolution of E-Government among Municipalities: Rhetoric or Reality? Public Administration Review, 62, 424-433. https://doi.org/10.1111/0033-3352.00196

[15] Chadwick, A. (2003) Bringing E-Democracy Back in Why It Matters for Future Research on E-Governance. Social Science Computer Review, 21, 443-455. https://doi.org/10.1177/0894439303256372

[16] Lu, Y. and Ramamurthy, K. (2011) Understanding the Link between Information Technology Capability and Organizational Agility: An Empirical Examination. MIS Quarterly, 35, 931-954. https://doi.org/10.2307/41409967

[17] Vene Klasen, L., Miller, V., Budlender, D. and Clark, C. (2007) A New Weave of Power, People and Politics: The Action Guide for Advocacy and Citizen Participation. Practical Action Pub.

[18] Irvin, R.A. and Stansbury, J. (2004) Citizen Participation in Decision Making: Is It Worth the Effort? Public Administration Review, 64, 55-65. https://doi.org/10.1111/j.1540-6210.2004.00346.x

[19] Michels, A. (2011) Innovations in Democratic Governance: How Does Citizen Participation Contribute to a Better Democracy? International Review of Administrative Sciences, 77, 275-293. https://doi.org/10.1177/0020852311399851 
[20] Watson, R.T. and Mundy, B. (2001) A Strategic Perspective of Electronic Democracy. Communications of the ACM, 44, 27-30. https://doi.org/10.1145/357489.357499

[21] Shah, A. and Shah, S. (2009) The New Vision of Local Governance and the Evolving Roles of Local Governments. Journal of Public Administration.

[22] Burgess, J.E., Foth, M. and Klaebe, H.G. (2006) Everyday Creativity as Civic Engagement: A Cultural Citizenship View of New Media.

[23] Laudon, K.C., Traver, C.G. and Elizondo, A.V.R. (2007) E-Commerce. Pearson/ Addison Wesley, Vol. 29.

[24] Orlikowski, W.J. and Barley, S.R. (2001) Technology and Institutions: What Can Research on Information Technology and Research on Organizations Learn from Each Other? MIS Quarterly, 25, 145-165. https://doi.org/10.2307/3250927

[25] Brillantes, A.B. and Fernandez, M.T.F.T. (2011) Restoring Trust and Building Integrity in Government: Issues and Concerns in the Philippines and Areas for Reform. International Public Management Review, 12, 55-80. 